Chapter 6

\title{
Creating Modern Community Conservation Organizations and Institutions to Effect Successful Forest Conservation Change
}

\author{
Robert H. Horwich, Sam Shanee, Noga Shanee, \\ Arnab Bose, Mark Fenn and Joydeep Chakraborty \\ Additional information is available at the end of the chapter \\ http://dx.doi.org/10.5772/61133
}

\begin{abstract}
Despite increased investment, current conservation strategies have failed to stop environmental degradation and loss of biodiversity of the earth's ecosystems with consequent climate change. Community Conservation's (CC) 30 years of experience has produced a successful, cost-effective, field-tested flexible formula to catalyze communities to stop deforestation and biodiversity loss. Our method focuses on four concepts: 1) catalyzing projects, leaving ownership to on-site community-based organizations (CBOs) or local nongovernmental organizations (NGOs); 2) encouraging creation of CBOs; 3 ) helping build complex federations or networks for a stronger community voice; and 4) creating conservation contagion for regional change. Based on trust, we initially make the community aware of their special forests and wildlife and ask their help in protecting them. Then we help them create CBOs and build federations of conservation activists to strengthen and empower them to manage their projects and their natural resources. By bringing community members to interact together from within a large region, we strive to create conservation contagion. Case histories from Assam, India; northern Peru; the Huon Peninsula in Papua New Guinea; Madagascar; Belize; and Wisconsin, USA demonstrate successes based on the formation of $\mathrm{CBOs}$ and community federations, allowing communities to play a powerful role in protecting and restoring forests.
\end{abstract}

Keywords: CBOs, community-based organizations, community conservation, institutions, NGOs 


\section{Introduction}

Despite increased financial resources, current conservation strategies, focused mainly on protected areas, have generally failed to stop environmental degradation, contain the rapid loss of biodiversity [1] and stem deforestation of the earth's forests [2-4] with consequent climate change [1, 5]. Billions of dollars over past decades have yielded few results $[2,5,6]$.

The rise of alternative conservation methods involving local communities in the early 1980s generated controversy [7-11] mainly due to lumping of all community-based conservation projects. Yet, small community conservation projects (CCPs) and large integrated conservation and development projects (ICDPs) have very different philosophies, concepts and actions with most controversy and failure attributed to ICDPs $[3,12]$. Today, there are thousands of CCPs [13-15] replacing community-based institutions which were once common globally, to manage forests [16, 17], fisheries [18] and water resources [17].

Some social scientists have been critical of community conservation [10, 11]. Others question whether rural communities can manage their forests and natural resources cooperatively [19, 20]. Yet still others question effectiveness of protected areas [21, 22] noting successes in community-based management systems outside protected areas [23].

What has emerged from what we describe in this article is a highly successful, cost-effective, field-tested method of community conservation [2, 3, 24, 25]. Not just an alternative, it can strengthen traditional conservation methods and protected areas that lack financial and human resources to succeed alone. It is a solid solution to environmental degradation [2, 3] of landscapes through building complex community organizations out of small, simpler ones [3, 25]. This is not surprising since many rural communities show favorable characteristics toward reduction of forest loss: 1) they live on-site where deforestation occurs; 2) they once had successful forest management organizations/institutions; 3) they have indigenous knowledge of the area; and 4) their numbers, thought detrimental, are potential conservationists [2, 3]. Indeed, when asked for help they have responded as conservationists.

At the center of successful CCPs is the creation of new conservation organizations or institutions managed by empowered communities. Such institutions in practice $[2,3,25]$ and research [26] have proved effective in forest conservation and management [21-23, 26-31].

Since our early work in Belize, Community Conservation (CC) has focused on creating community organizations and complex institutions to protect and manage community projects and environmental landscapes (Table 1). Since 1984, we have evolved a field-tested flexible formula to facilitate catalyzing conservation contagion [3] to stop deforestation and biodiversity loss.

Generating conservation contagion [3] encourages local people as on-site conservationists [1, 14]. When conservation practitioners act as catalysts rather than project owners, communities respond favorably and contagion and community activism can emerge [3](see presentations on www.communityconservation.org). Conservation contagion often has a nonlinear effect $[32,33]$ as described in the following case histories. Our practitioner conclusions have a high 
1986 - Naïve attempt to create Board or Committee to oversee the CBS in Belize, eventually leading to the Woman's Conservation Group managing the project in 1998

1988 - Begin work with newly formed Ferry Bluff Eagle Council in Wisconsin, USA

1992 - Initiate Kickapoo Reserve to create valley-wide Kickapoo Community Sanctuary in Wisconsin, USA

1997 - First proposal to create a formal federation of community-based organizations to co-manage protected areas of Belize, resulting in UNDP grant to create the federation. 1999 - Attempt to carry out the project goals curtailed by project steering committee changing project goals

1998 - Creation of successful federation of community groups protecting the Manas Biosphere in Assam, India by 2004-2006; creation of two federations of 34 surrounding villages to protect Kakoijana Reserve Forest

2004 - Advising the creation of a federation of clan landowners in Papua New Guinea resulting in the Tree Kangaroo Conservation Program initiating the first Conservation Area in Papua New Guinea in 2010

2008 - Using new Madagascar laws to create federations of community-based groups to create around protected areas as buffer areas with federation network in Toliara District

2009 - Using new 2002 Peru laws, to begin expansion of Yellow Tailed Woolly Monkey Conservation Project to encourage community groups to create community conservation concessions to protect and manage lands with potential to create a network of these groups

2010 - Using new Ghana laws, expand existing community-based CREMA of 15 surrounding villages to protect Cape Three Points Forest Reserve

Table 1. Attempts and practices to create complex community institutions.

probability of success and are supported by social science research [26]. This paper discusses the evolution of community organizations and institutions guided by nongovernmental organizations (NGOs) and shaped by historical events using examples from India, Peru, Papua New Guinea, Madagascar, Belize and the USA.

\section{Methods}

Each project had its own methods of research, education, economic development, and community development integrating community members with the ultimate goal of conservation. They followed a series of 10 stages that we identified: 1 ) identify the project; 2 ) initiate or encourage a community-based organization (CBO); 3) train the $\mathrm{CBO} ; 4)$ collect biological and sociological data; 5) develop community/outreach; 6) develop management and operation plans; 6) develop infrastructure; 7) formalize the plan; 8) implement the plan; 9) formalize management and project components; 10) terminate advisory role [34].

The projects' bases were social: 1) initiate contact with the community and ask their help; 2) build trusting social relationships; 3) participatory education; 4) identification of leaders and 5) supporters; 6) development of a formal infrastructure and plans; 7) form local networks of conservation activists; 8) diffusion from the target village to other communities to generate conservation contagion; and 9) develop vertical contacts with government and other NGOs (for specific project methods see: $[2,3,25,35,36]$ ). 


\section{Results - Case histories}

\subsection{Assam, India - Order out of chaos}

The Golden Langur Conservation Project (GLCP) was initiated in 1998 to test methods and concepts developed in Belize, in a challenging new political situation in India with a high human population, militants in the forest, ethnic violence and 250, 000 internal refugees [2, 3, 25]. Given the potential for conservation contagion, the project focused on regional change of the entire Indian range of the golden langur, Trachypithecus geei. Contagion began first with participating researchers who focused on the flagship species. Following many meetings and workshops involving communities, NGOs and governmental agencies, the GLCP formed the Manas Biosphere Conservation Forum to focus on the main Indian range of the golden langur. As conservation contagion gathered momentum, community groups were catalyzed.

Kakoijana, a $17 \mathrm{~km}^{2}$ isolated Reserve Forest, with $95 \%$ deforestation became a model for future regional work. It was surrounded by 34 villages that formed forest committees to replant degraded areas and Self Help Groups to improve villagers' economic condition with microenterprises [3, 25; Bose pers.com.]. Interaction of forest committees and Self Help Groups empowered communities to protect specific forest areas. Eventually, all villages patrolled forested areas and formed two federations to protect the regenerating Kakoijana Reserve Forest and its langurs resulting in an increase of forest canopy cover from $5 \%$ to $80 \%$, an increase in the langur population from less than 100 to over 500 [3] and an increase of other avian and mammalian species.

Focused on the Manas Biosphere in 2000, new CBOs emerged from conservation contagion generated by community meetings and workshops throughout the Biosphere. Four celebrations within the Manas Biosphere attracted progressively larger crowds of 6, 000 to 35, 000 participants from the government, NGOs and communities. Following a cessation of militant violence, including an accord in 2004 with the Central Government of India by the Bodoland Liberation Tigers and a ceasefire by the National Democratic Front of Bodoland, more conservation gains occurred.

Despite the peace, illegal loggers still threatened government staff and community residents. In response, the late Rajen Islari, coinitiator of the GLCP, and Kampa Borgoyari, Minister of Environment of the newly formed Bodoland Territorial Council, created the first paid community forest protection force to protect the western Reserve Forests of the Biosphere. This stimulated the formation of other community protection forces with 19 CBOs composing the Unified Forest Conservation Network (Table 2, Figure 1). Sixteen of those CBOs protect almost the entire 285, 000 hectare Manas Biosphere. Most illegal logging has ceased although there are still problem areas. The expanded project became the Manas Elephant Protection Project. The total Indian golden langur population increased from 1500 [37] to over 5600 golden langurs [3, 38] with evidence that elephant [39] and tiger [40] populations may be increasing. The combined efforts of government, NGOs and CBOs catalyzed by the GLCP, resulted in the lifting of the "in danger" listing of UNESCO on the Manas Biosphere. 


\begin{tabular}{|c|c|c|c|c|}
\hline Community Groups & Date Form & Location & Protected Area & \# vol \\
\hline 1. Green Forest Conservation & 2006 & Kachugaon & $\begin{array}{l}\text { Kachugaon RF \& helps } \\
\text { others }\end{array}$ & 116 \\
\hline 2. Jharbari-Nounwgwr Eco-tourism Society & 2007 & Jharbari & Chirang RF & 40 \\
\hline 3. Biodiversity Conservation Society & 2006 & Ultapani & Chirang RF & 40 \\
\hline 4. Green Earth & 2010 & Labnypur & Chirang RF & 11 \\
\hline 5. New Horizon & 2006 & KoilaMoila & Manas RF & 5 \\
\hline $\begin{array}{l}\text { 6. Raigajli Ecotourism \& Social Welfare } \\
\text { Society }\end{array}$ & 2006 & Kuklung & Manas RF & 30 \\
\hline $\begin{array}{l}\text { 7. Panbari Manas NP Protection \& } \\
\text { Ecotourism Society }\end{array}$ & 2006 & Panbari & $\begin{array}{l}\text { Manas NP - Panbari } \\
\text { Range }\end{array}$ & 28 \\
\hline 8. United Social Welfare Society & 2012 & Labdanguri Kahitema & $\begin{array}{l}\text { Manas NP- Bansbari } \\
\text { Range }\end{array}$ & 26 \\
\hline 9. Swmkwr Mittinga Onsai Afat & 2005 & Bansbari & $\begin{array}{l}\text { Manas NP -Bansbari } \\
\text { Range }\end{array}$ & 40 \\
\hline $\begin{array}{l}\text { 10. Manas Bhuyapara Conservation \& } \\
\text { Ecotourism Society }\end{array}$ & 2007 & Bhuyapara & $\begin{array}{l}\text { Manas NP - Bhuyapara } \\
\text { Range }\end{array}$ & $\mathrm{a}_{25}$ \\
\hline 11. Manas Maozagendry Ecotourism Society & 2006 & Koklabari & Manas NP Koklabari & 30 \\
\hline 12. Manas Agrang Society & 2006 & Simlibari & $\begin{array}{l}\text { Manas NP- Bhuyapara } \\
\text { Range }\end{array}$ & 24 \\
\hline $\begin{array}{l}\text { 13. Manas Souci Khonghor Ecotourism } \\
\text { Society }\end{array}$ & 2006 & Barama & Dhira RF & 69 \\
\hline 14. Manas Chowki Eco-Tourism Society & 2011 & Uttarkuchi Subankhata & aSubankhata RF & 20 \\
\hline $\begin{array}{l}\text { 15. Green Valley Forest \& Wildlife Protection } \\
\text { Society }\end{array}$ & 2011 & Nonaipara & $\begin{array}{l}\text { Khalingduar RF, } \\
\text { Barnadi WS }\end{array}$ & 10 \\
\hline 16. Green Leaves Society & 2007 & Khoragat & $\begin{array}{l}\text { Manas NP - Khoraghat } \\
\text { Range }\end{array}$ & t 21 \\
\hline 17. Bodoland Forest Protection Force & 2006 & Balapara & $\begin{array}{l}\text { Manas NP - Rupai \& } \\
\text { Khoraghat Ranges }\end{array}$ & 59 \\
\hline 18. Dwi Bajrum Eco-Tourism Society & 2014 & Udalguri & $\begin{array}{l}\text { Manas NP - } \\
\text { Bhairabkunda Area }\end{array}$ & 20 \\
\hline 19.Daoka Raja Eco-tourism Society & 2013 & Chakrasila & Chakrasila WS & \\
\hline $\begin{array}{l}\text { United Forest Conservation Network - BTC } \\
\text { (Umbrella Federation) }\end{array}$ & 2009 & & $\begin{array}{l}\text { Manas Biosphere } \\
\text { Reserve }\end{array}$ & Total 614 \\
\hline 19. Green Conservation Federation & 2005 & & Kakoijana RF & \\
\hline 20. Nature Guard & 2005 & & Kakoijana RF & \\
\hline
\end{tabular}

Table 2. Assam, India community groups formed (RF = Reserve Forest, NP = National Park WS = Wildlife Sanctuary). 


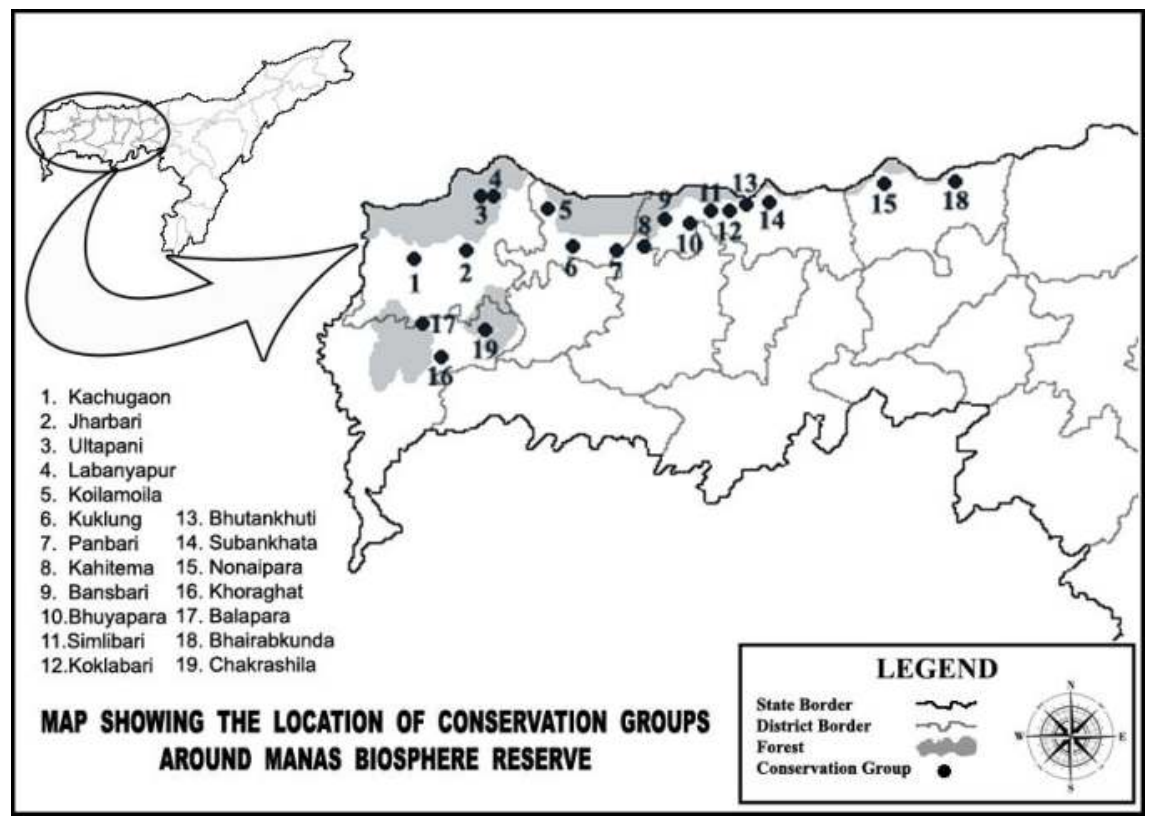

Figure 1. Map of the Manas Biosphere Reserve and other areas protected by community groups (numbers correspond with Table 2). Source: original.

Nature's Foster (NF), our main NGO partner, initiated a new Biosphere project focused on human elephant conflict, under the Assam Haathi Project that focused on a fringe village where elephants damaged village gardens and rice paddies. NF proposed to create a protective electric fence (Figure 2) if the village would provide labor and posts cut from non-protected forests. Participating families would pay a small maintenance fee and maintain the fence. Fiftythree families agreed to the proposal but one group declined to participate.

The complex community institution that resulted was modeled after the Kakoijana federations and the Manas Unified Forest Conservation Network. This institution is a complex multicentric federation built on smaller groups [26]. The fence that was to be maintained included two solar-powered electric stations, and a number of gates to be closed at night when the electricity was turned on. For ease in dividing tasks for fence maintenance, the seven hamlets created nine smaller groups of three or four people to do specific jobs, including maintenance of the power system and wires, opening and closing gates and cutting and clearing vegetation around the electric fence. An administrative committee represented by all hamlets and the two cultural communities, Bodos and Rajbanshis was appointed to administer and maintain the system. Thus far, the $6 \mathrm{~km}$ fence encircling $2.5 \mathrm{~km}^{2}$ of village area has functioned well for the past four years with no elephant depredations from the adjacent Manas Biosphere forests. The reticent families have since joined the project since they continued to suffer depredations. Other fringe communities have requested similar projects and negotiations are being carried out to interest the Bodoland Territorial Council in more projects. 


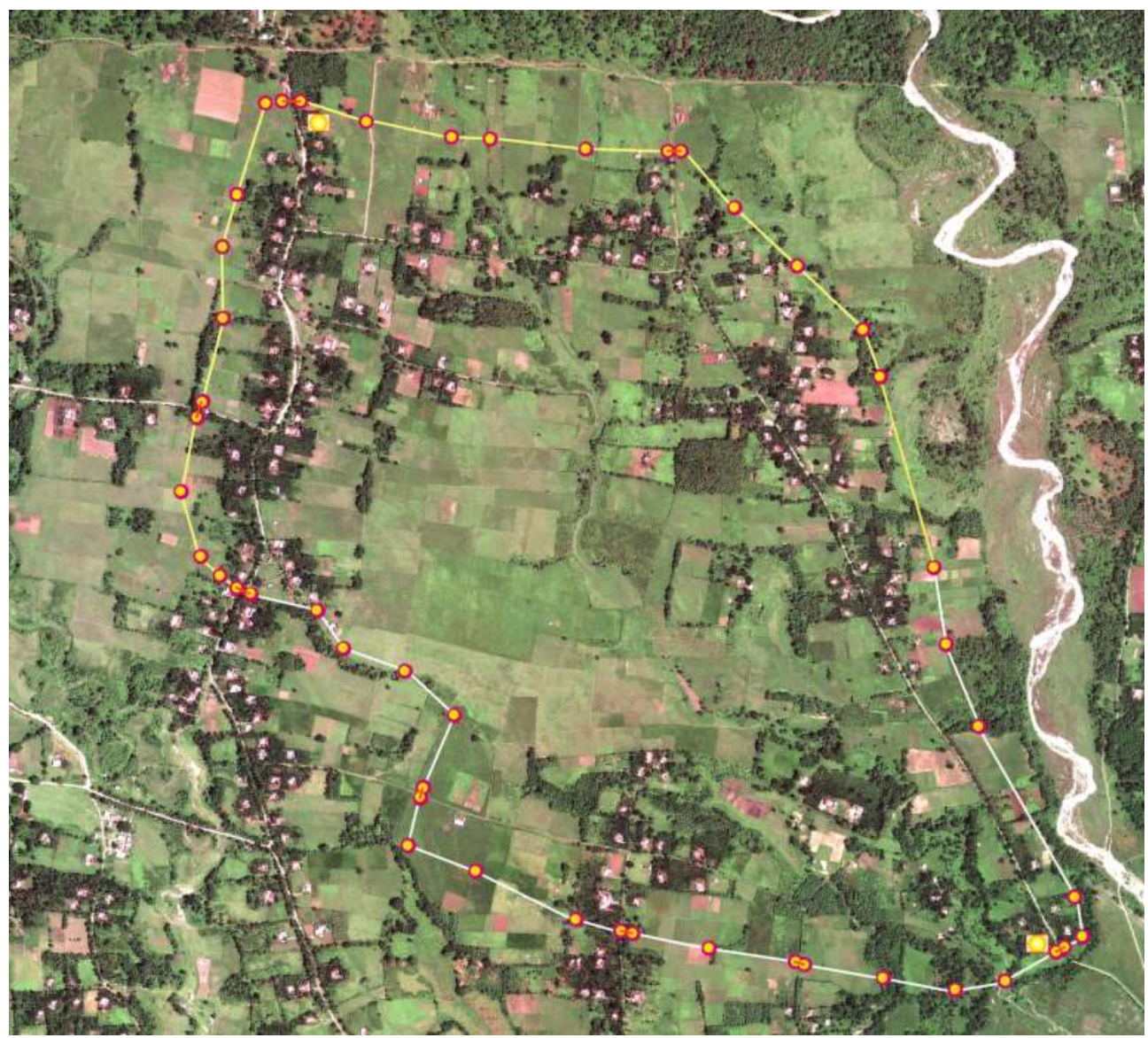

Figure 2. Aerial photo of the original solar electric fence (omiting the village in the bottom corner). Source: original

\subsection{Northern Peru - Law and conservation contagion for community management and protection}

The Yellow Tailed Woolly Monkey Project (YTWMP) was initiated by Neotropical Primate Conservation (www.neoprimate.org) in 2007 focused on creating a community reserve corridor between two protected areas in the cloud forest of northern Peru to protect populations of the endemic Critically Endangered yellow-tailed woolly monkey (Lagothrix flavicauda). Initially, the community was suspicious of the intentions of foreigners promoting conservation [41]. Rapid progress occurred through conservation contagion from two community-oriented workshops through help from the Ronda Campesina, a traditional CBO that establishes community security where there is not adequate government protection [42]. In all other areas, contagion has worked through word of mouth and media to create situations where the community groups have solicited help from the project. 
With conservation contagion, the YTWMP expanded its goals, capitalizing on the 2002 Peruvian laws, by helping communities form CBOs to create conservation concessions and private conservation areas. The YTWMP, using its flagship species, expanded to focus on a landscape of endemism bounded by the Marañón and Huallaga rivers. Table 3 lists the groups the YTWMP is helping with concessions. Figure 3 locates the protected areas. The project is also helping to create local federations to function as community networks to educate themselves to manage their community reserves. As the project expands, it has the potential to incorporate as many as 50 community CBOs, managing an additional 500, 000 hectares of cloud forest and lower tropical rain and dry forests. This Marañón-Huallaga community landscape is a subcenter of endemism within the Tropical Andes Biodiversity Hotspot [43]. Three endemic primates inhabit the landscape: the yellow-tailed woolly monkey, the Andean night monkey (Aotus miconax) and the San Martin titi monkey (Callicebus oenanthe). The area also contains 13 additional primate and numerous other endemic species.

\begin{tabular}{|c|c|c|c|c|}
\hline Group or Towns & $\begin{array}{l}\text { Date } \\
\text { Formed }\end{array}$ & Community Protected Area & Hectares & $\begin{array}{l}\text { Stage of } \\
\text { Concession }\end{array}$ \\
\hline 1, & 2009 & San Angel's Gardens & 7,418 & Awarded \\
\hline 2. & 2010 & Gran Simacache & 41,269 & Awarded \\
\hline 3. & 2009 & Iguahuana Dry Forests of Delta & 423 & Awarded \\
\hline 4. & 2011 & Hocicon & 509 & Created \\
\hline 5. & 2008 & Pampa del Burro & 2,700 & Awarded \\
\hline 6. & 2010 & Shitaryacu & 1,592 & Awarded \\
\hline 7. & 2010 & Tres Quebradas & 4,177 & Awarded \\
\hline 8. & 2007 & Hierba Buena Allpayacu & 2.282 & Awarded \\
\hline 9. & 2010 & Copallin & 11,549 & Awarded \\
\hline 10. & 2012 & Alto Renaco & 3,372 & Last stages \\
\hline 11. & 2011 & El Quinillal & 11,540 & Awarded \\
\hline 12. & 2013 & Sacha Runa & 2,538 & Awarded \\
\hline 13. & 2013 & Larga Vista 1 & 22 & Awarded \\
\hline 14. & 2013 & Larga Vista 2 & 23 & Awarded \\
\hline 15. & 2014 & The Monkeys Jungle & 324 & Created \\
\hline 16. & 2014 & Maorna & 874 & Created \\
\hline 17. & 2015 & Quiscarumi & 11 & Created \\
\hline 18. & 2010 & Berlin & 98 & Awarded \\
\hline \multicolumn{5}{|l|}{ NGO PA } \\
\hline 19. AMPA & 2008 & El Breo & 113,826 & Awarded \\
\hline 20. AMPA & 2012 & Pucunucho & 24 & Awarded \\
\hline 21. AMPA & 2013 & Mangapaquina & 14 & \\
\hline
\end{tabular}

Government PA 


\begin{tabular}{lllll}
\hline Group or Towns & $\begin{array}{l}\text { Date } \\
\text { Formed }\end{array}$ & Community Protected Area & Hectares & $\begin{array}{l}\text { Stage of } \\
\text { Concession }\end{array}$ \\
\hline 22.Government & 2010 & Rio Nieva Resrved Zone & 36,348 & Last stages \\
\hline 23.Government & 2009 & Cordilla de Colon National Sanctuary & 39,216 & Created \\
\hline $\begin{array}{l}\text { 24.Government } \\
\text { community co- } \\
\text { management }\end{array}$ & 2009 & Chayunain Communal Reserve & 23,598 & Created \\
\hline 25.Government & 1987 & Alto Mayo Protected Forest & & Created \\
\hline
\end{tabular}

Table 3. Peru community groups formed and other protected areas worked with.

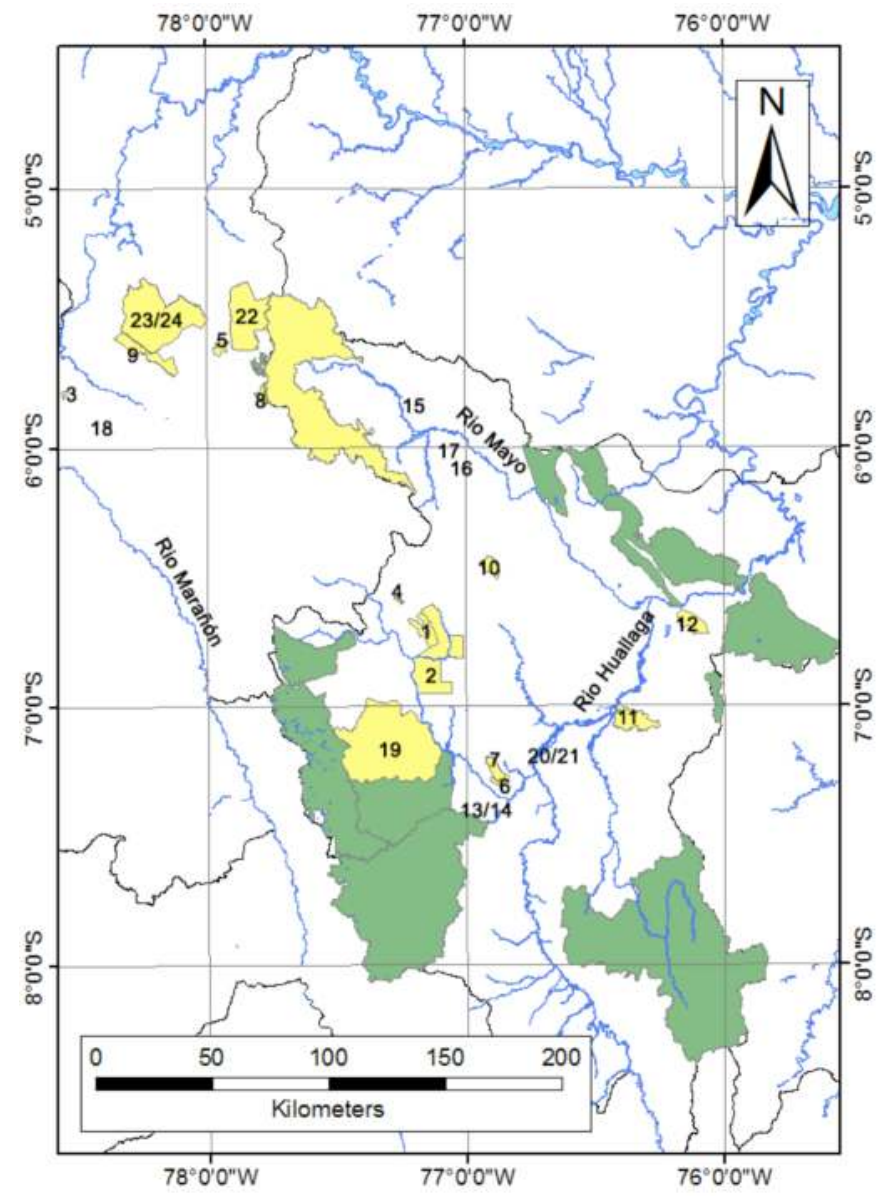

Figure 3. Map of the Mareñón-Huallaga Landscape in Northern Peru indicating the Government Protected Areas (green) , NGO and Community Reserves (yellow) (numbers correspond with Table 3). Source: original 


\subsection{Huon Peninsula, Papua New Guinea (PNG) - First conservation area}

The Tree Kangaroo Conservation Program (TKCP) began in 1996 to study the endangered Matschie's tree kangaroo (Dendrolagus matschiei), endemic to the Huon Peninsula and expanded into a community conservation initiative [44], focused on the area defined by the Yopno, Urawa and Som rivers (YUS area). When CC joined the initiative, three clans were participating to create a Wildlife Management Area (WMA) similar to other communityprotected areas [45]. However, WMAs had many disadvantages. PNG law draws on Australian law to include customary groups [46] with local land tenure systems and the inherent land rights $[47,48]$ in which indigenous clans own $97 \%$ of the land. By 1991, less than 3\% of PNG lands had protected status [49-51] and most (88\%) were WMAs created under the Fauna Act of 1966. Thus, novel approaches were necessary to conserve forests and wildlife yet retain clan control of their lands [52].

Papua New Guineans' view of the natural world shows strong attachment to their lands, rivers, and mountains - reflected in the popular saying among many rural Papua New Guineans that "land is life" [53]. Although they have managed their lands for thousands of years, traditional views have been partially supplanted by Christian teachings complicated by modern commercialism [54], with pressure from the Land Tenure Conversion Act that provides a mechanism to convert customary ownership to private land ownership [46]. Recent YUS history laid foundations for clans working together in the TKCP. Originally, Yupno people lived in scattered groups but were moved to create villages after the Second World War with pressure from the Lutheran mission, to establish a "Christian Community" [55]. Thus, clans of different descent groups live together in villages.

After a first visit in 2002, CC wrote a proposal to create a Conservation Area by 1) gathering legal information, 2) facilitating landowner visits to other protected areas, 3) forming a local conservation group, and 4) creating a landowner group to develop a management plan. The Conservation Area has strong objectives similar to National Parks and is more comprehensive than WMAs [52]. Although the Conservation Areas Act was enacted in 1978, it was never previously used since there was no functioning National Conservation Council [56, 57] that determines the criteria, rules and regulations for the Conservation Area. This council was appointed in 2003, perhaps stimulated by the TKCP, opening the way for the YUS Conservation Area [52]. The TKCP and the YUS clans chose the Conservation Area because of its strength and its maintenance of the clans' decision-making rights over their customary lands [52].

By 2003, the TKCP had collected pledges for 36, 363 hectares from 26 clans [58] (Figure 4). The first meeting of clan landowners and the Department of the Environment and Conservation (DEC) occurred in 2004 and a proposal for the YUS Conservation Area was submitted [59]. The TKCP next worked with the YUS Local Level Government, the District Government and the Morobe Provincial Government to gain local government approval. Finally, they worked with the National DEC to develop the proposal for official approval by the PNG National Executive Council (NEC) [59, 60]. The final proposal to the NEC [60, 61], declared over 68, 182 hectares of over 100 clans from 37 villages [61]. The National Government approved the YUS Conservation Area and it was gazetted in January 9, 2009 [60]. 


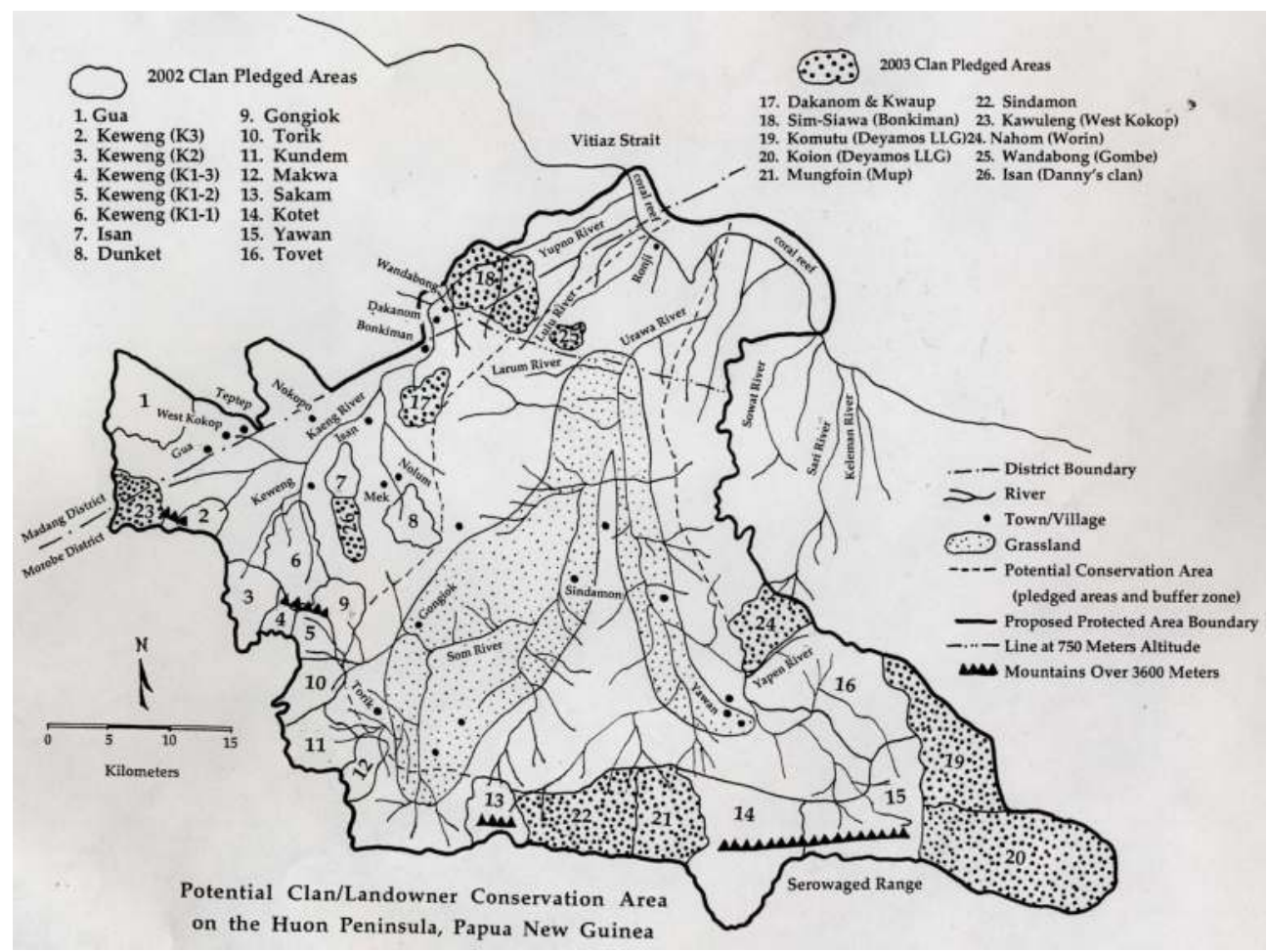

Figure 4. Initial map of the developing YUS Conservation Area in process indicating the 26 clans represented by 2003. Source: original.

Since the state's role has been ineffective in accommodating existing private land ownership [62], the YUS Conservation Area, the first in PNG, and its community comanagement role [63, 64] may strengthen the government's role. Comanagement balances local interests with a legal basis. Although landowners cede some rights, the Management Committee reflects the interests of the landowners as well as the Provincial and National governments [56].

The YUS Conservation Area, a model project [60, 65], now protects 75, 676 (187, 000 acres) hectares and includes 45 villages within the Finisterre and Sarawaged mountain ranges [66] (Figure 5). The TKCP trained landowners to develop management plans and will develop a guide for other communities [60]. It has formed a local $\mathrm{CBO}$ to advise the management committee and an in-country NGO and has established a trust fund to maintain the YUS Conservation Area.

Another PNG project, the Tenkile Conservation Alliance, that focused on two other tree kangaroo species has been working steadily in the same direction. Given these two projects, the laws and NGOs supporting the community approach, Community Conservation submitted a proposal to Conservation International to use a series of workshops to stimulate conservation contagion for initiating other Conservation Areas in PNG [67]. 


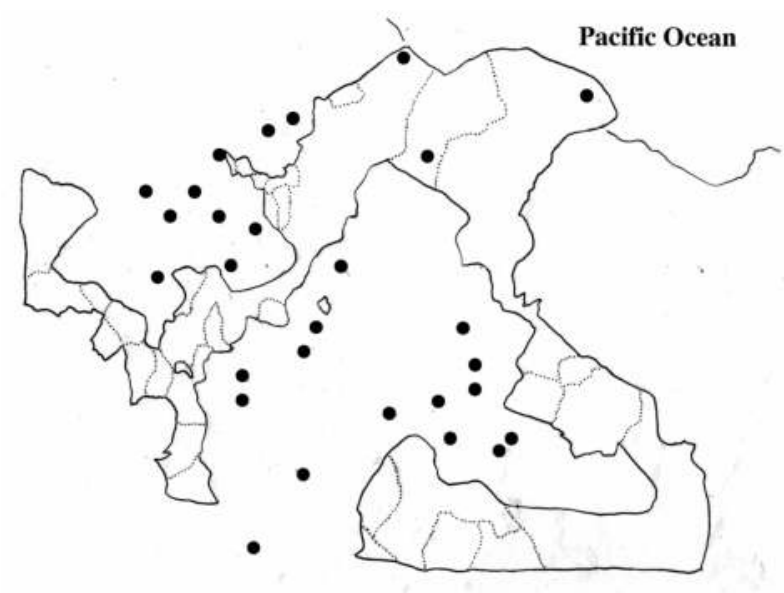

Figure 5. Map of the completed YUS Conservation Area of 187, 000 (75, 676ha) acres. Dotted lines indicate clan boundaries, solid dots indicate villages. Source: [66].

\subsection{Southwest Madagascar - A plan laid out}

A consortium of government and NGOs made a regional plan to create federations of community reserves to support existing protected areas and to triple the number of protected areas in accordance with the Madagascar National Environmental Action Plan.

In recent times in Madagascar, the local perception that forests belong to the "fanzakana" (government) led to forest degradation from lack of enforcement and loss of respect for the government $[68,69]$. In 1996, the government stimulated community-based natural resource management through the GELOSE (Gestation Locale Securise) law that encouraged contracts between the forest service, the local municipality, and a voluntary community association (COBA, Communaté de Base). This cumbersome GELOSE was simplified by Contractual Forest Management (GCF) in 2000 through transference of forest management rights to the communities. Thus, in the third phase of the National Environmental Action Plan (NEAP) that emphasized a landscape approach supported by GELOSE and GCF, over 400 GELOSE contracts were formed throughout Madagascar [69]. By 2009, over 150 such contracts had been signed in the south and southeast alone and the figure is now well over 250 in the south and southwest Madagascar.

Since 2005, after a socioeconomic assessment of southwestern Madagascar [70], WWF and the National Association for the Management of Protected Areas in Madagascar (ANGAP) fostered community comanagement of the dry forest landscape in support of the Durban accord to triple the amount of protected areas in Toliara District [70]. They worked with communities to form village associations and encouraged the GELOSE law for community comanagement [71]. This legal transfer of management responsibility from the state to villages or communes includes a traditional agreement (dina) signed by the village association (COBA), the commune and a government representative, usually the Waters and Forest Service (L'Eaux et Forêts) for forested areas [69, 71]. 
Once functional and strong associations for land and natural resource management are formed, the areas of community protective influence can be demarked. Then community comanagement federations are formed around community-protected lands often around public protected areas to work with NGOs and ANGAP or other agencies. Coordinators can then strengthen the associations and federations to further their goals by training the community members in the 13 topics [72] relative to both technical and governance aspects of community management. The associated COBAs then elect a coordinator. Coordinators and participating NGOs can train community members with a 1-2 year training course while living in or frequently visiting the villages. Short-term workshops could supplement the long-term on-site training and tutoring. Such a 2-year program would prepare the associations and staff for formal management. The comanagement federation would work with ANGAP or the Waters and Forest Service to create a management plan to include an active forest protection force to patrol and post their lands to discourage encroachers. Associations would set up forestation programs for fuel-wood and other future needs. Plantations would emphasize forest corridors between Federation lands where feasible.

Table 4 and Figure 6 indicate the plan for the following four Regions of south-southwestern Madagascar: Menabe, Atsimo-Andrefena, Androy, and Anosy. This evolving conservation work emphasizes supporting and expanding the areas under protection by having communities work together with ANGAP and NGOs to both strengthen government protected areas and connect them with community protected areas.

\begin{tabular}{|c|c|c|c|c|c|}
\hline Group & Type & State Protected Area & Community PA & Type & Ha \\
\hline Alokaina & OPCI & 1 Andranomena SR & 2 Menabe Antimena & APC & 1.6420 \\
\hline \multirow[t]{2}{*}{ Agnalamaitso } & & & & & 2. 195000 \\
\hline & & & 3 Allee des Baobabs & APC & small \\
\hline Hahitamami & $\mathrm{AI}$ & 4 Kirindy Mite NP & & & 72200 \\
\hline Fimami & $\mathrm{AI}$ & 5 Mikea NP & & & 250000 \\
\hline \multicolumn{2}{|c|}{ Velondriake Fiama AV } & & 6 Velondriake & APC & 80000 \\
\hline Tsifota \& & AV & & 7 Honco & APC & $>4000$ \\
\hline \multicolumn{6}{|l|}{ Fiherenamasy } \\
\hline Mitoimafi & AI & & 8 PK32-Ranobe & APC & 77851 \\
\hline Fimihara & AV & & 9 Jardin des Roses & $\mathrm{APC}$ & $>200$ \\
\hline Filobe & AV & & 10 Belalanda & APC & .3000 \\
\hline Tamia & AV & & 11 Tsinjoriake & APC & $>15000$ \\
\hline Ohemiha & OPCI & & 12 Amoroni Onilahy & APC & $>12000$ \\
\hline Club Tsita & $\mathrm{AV}$ & & 13 Ranomay & APC & $>300$ \\
\hline \multirow[t]{2}{*}{ Fimimano } & $\mathrm{AI}$ & & 14 Nosy Ve \& marine park & $\mathrm{APC}$ & $>6000$ \\
\hline & & & Tsimanempesotse & & \\
\hline Tsitinginy & AV & & 15 Honko, Nosy Satrana & $\mathrm{APC}$ & $>500$ \\
\hline \multicolumn{6}{|l|}{ Andrangy } \\
\hline \multirow[t]{2}{*}{ Rodobey } & AICPM & 16 Tsimanampesotse NP & & & 43200 \\
\hline & & & & & 177000 \\
\hline
\end{tabular}




\begin{tabular}{|c|c|c|c|c|c|}
\hline Group & Type & State Protected Area & Community PA & Type & На \\
\hline Hihitse & AI & & 17 Menarandra Sud & $\mathrm{APC}$ & $>4000$ \\
\hline Komiholo & OPCI & & 18 Angavo & $\mathrm{APC}$ & $>8000$ \\
\hline \multirow[t]{5}{*}{ Fikasana } & OPCI & & 19 Nord Ifotaka & $\mathrm{APC}$ & $>15000$ \\
\hline & & & 20 Sud-Quest Ifotaka & & \\
\hline & & & 21 Corridor PI-PII & & \\
\hline & & & Andohahela & & \\
\hline & & & 22 Behara-Tranomaro & & \\
\hline Makarefi & OPCI & & 23 Ankodida & APC & \\
\hline
\end{tabular}

Table 4. Madagascar community groups formed in southern and southwestern regions of Madagascar and official or estimated surface areas under national park or community conservation status. (Community group types include Intercommunal Associations - AI; Village Association - AV; Public Organization of Intercommunal Cooperation OPCI; and AICPM. Protected Area Types include National Park - NP; Special Reserve - RS; Community Protected Area - APC).

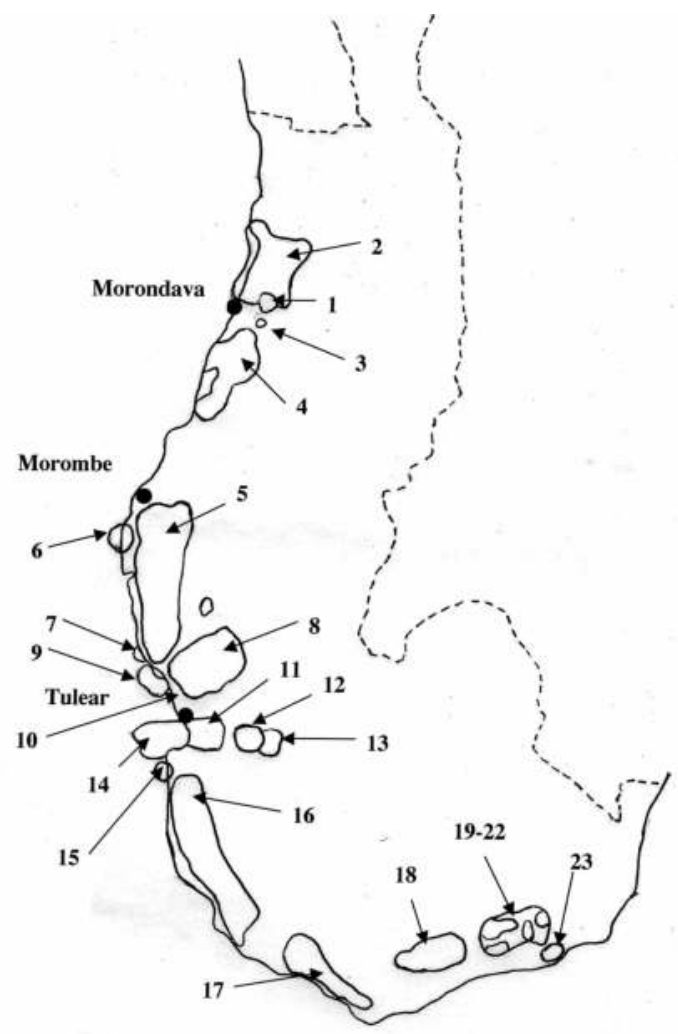

Figure 6. Map of Toliara Province in Southwestern Madagascar showing Community Protected Areas, Government Protected Areas, and Community Groups they are associated with (numbers correspond with Table 4). Dotted lines indicate the provincial border; dots are towns. Source: after WWF by Louise Jasper. 


\subsection{Belize - Missed opportunity for community comanagement}

The Community Baboon Sanctuary (CBS) was initiated in 1985 as an experiment to protect a viable population of black howler monkeys (Alouatta pigra) that is endemic to southern Mexico, northeastern Guatemala, and Belize. With the introduction of community conservation to Belize, we first saw evidence of conservation contagion [3]. As a result, many communities sought opportunities similar to what was occurring in the CBS in Belize. Many communities stimulated the Government of Belize to create protected areas and the government, with comanagement experience with NGOs, involved communities in comanagement through signing of memoranda of understanding (MOUs) [73] signing at least 20 community groups as comanagers (Table 5, Figure 7). Eventually, the Government of Belize incorporated community comanagement into government policy [74]. However, despite this, lack of financial support and government motivation [75] left many CBOs struggling to manage their protected areas.

\begin{tabular}{|c|c|c|c|c|c|}
\hline Group Name & $\begin{array}{l}\text { Group } \\
\text { Form. }\end{array}$ & $\begin{array}{l}\text { Year } \\
\text { Form. }\end{array}$ & PA Name & $\mathrm{Ha}$ & $\begin{array}{l}\text { Com } \\
\text { Stim. PA }\end{array}$ \\
\hline 1.Women's Conservation Group & 1998 & 1985 & Community Baboon Sanctuary & 4700 & Yes \\
\hline 2.Assn Fr of 5 Blues Lake NP & $1993 ?$ & 1994 & 5 Blues Lake NP & 1846 & Yes \\
\hline 3.Aguacaliente Management Team & 1996 & 1998 & Aguacaliente WS & 2485 & Yes \\
\hline 4.STACA & 1994 & 2001 & Billy Barquedier NP & 745 & Yes \\
\hline 5.Assn of Fr of Freshwater Creek & $1998 ?$ & 2001 & Honey Camp NP & 3533 & No? \\
\hline 6.Fr of Mayflower Bocawina NP & 1999 & 2001 & Mayflower Bocawina NP & 3570 & Yes \\
\hline 7.Itzamna Society & 2000 & 2001 & Noj Kaax Meen Elijio Panti NP & 5753 & Yes \\
\hline 8.Rio Blanco Mayan Association & 1994 & 1994 & Rio Blanco NP & 43 & Yes \\
\hline 9.Rancho Dolores EDG & $2000 ?$ & 2002 & Spanish Creek WS & 2728 & Yes \\
\hline 10.Green Reef & $1996 ?$ & 1996 & Bacalar Chico NP \& MR & 7166 & Yes \\
\hline 11.Friends of Swallow Caye & 1996 & 2002 & Swallow Caye WS & 4078 & Yes \\
\hline 12.TASTE to SEA & 2000 & 1996 & Sapodilla Cayes MR & 12500 & $?$ \\
\hline 13.FoN to SEA & 1993 & 1996 & Laughingbird Cay NP & 4600 & Yes \\
\hline 14.FoN to SEA & 1993 & 2003 & Gladden Spit \& Silk Cayes MR & 11808 & Yes \\
\hline 15.Friends of GraGra Lagoon & 1994 & 2002 & GraGra Lagoon NP & 600 & Yes \\
\hline 16.SATIIM & 1998 & 1994 & Sarstoon-Temash NP & 19025 & No \\
\hline 17.FAMRACC & $1998 ?$ & 1998 & Cay Caulker MR & 4395 & Yes \\
\hline 18.Guardians of the Jewel & $2000 ?$ & 1994 & Monkey Bay NP & 965 & No? \\
\hline 19.GPWSCMC & $2003 ?$ & 1998 & Gales Point WS & 4135 & No \\
\hline 20.SACD & 2007 & 1996 & Corozal Bay WS & 82049 & No \\
\hline TOTAL & & & & 176,724 & \\
\hline
\end{tabular}

Table 5. Belize Community Groups Formed (all except CBS are comanaged with the Government of Belize [from 76, 77] $($ Assn = Association, $\mathrm{Fr}=$ Friends, $\mathrm{EDG}=$ Environmental and Development Group, NP = National Park, FAMRACC $=$ Forest and Marine Reserve Association of Cay Caulker, FoN = Friends of Nature, GPWSCMC = Gales Point Wildlife Sanctuary Community Management Committee, SACD = Sarteneja Alliance for Conservation and Development, $\mathrm{SEA}=$ Southern Environmental Association, STACA = Steadfast Tourism and Conservation Group, TASTE = Toledo Association for Sustainable Tourism and Empowerment). 


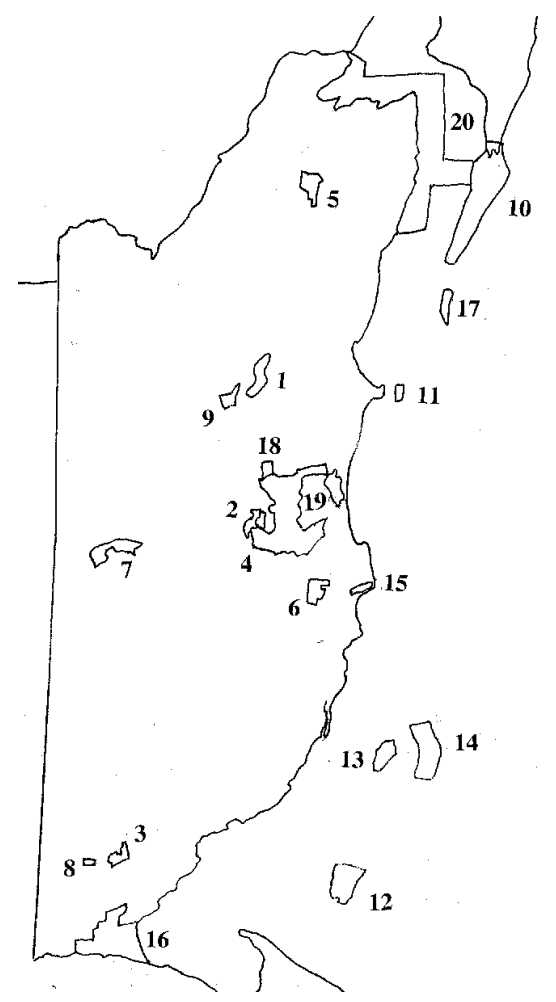

Figure 7. Map of Belize with Community Baboon Sanctuary (No.1) and Protected Areas comanaged with informal and formal agreements with Government of Belize Departments of Forestry and Fisheries (numbers correspond with Table 5). Source: $[76,77]$.

Seeing the possibilities for creating a strong community comanagement system, CC wrote a proposal to be administered by the Protected Areas Conservation Trust (PACT), a parastatal Belizean organization, for a GEF grant to develop five community projects and a communitybased network for all CBOs in the country [78]. The projects selected by PACT included Sarstoon-Temash National Park, Freshwater Creek Reserve Forest, Gales Point Manatee, Five Blues Lake National Park, and Aguacaliente Wildlife Sanctuary. As a result of CC's action to involve communities in the management of the Sarstoon-Temash National Park [3, 79, 80], an indigenous NGO, Sarstoon Temash Institution of Indigenous Management (SATIIM), was initiated and they wrote their own proposal that was consequently funded.

CC's proposal [78] was funded and the project began in 1999, with CC staff as project advisers. After 6 months, the project steering committee changed the project goals [75] and CC staff were eliminated from the project. PACT hired a young Belizean woman with a Masters degree but no community conservation experience and the steering committee acted as project advisers. As a result of these changes, the project was deemed a failure [81] and the $\$ 750,000$ and added funds were essentially wasted with no hope of renewal. 
After the project completion, CC staff attempted to recreate the community comanaged network. They worked without funding with Matt Miller, a Peace Corps (PC) staff to develop the network through PC volunteers placed in communities managing protected areas [82]. When Miller's PC affiliation ended, it was impossible to proceed, and the communities have been left to struggle on their own. A few years later in 2007, the Association of Protected Areas Management Organizations (APAMO) was formed, perhaps influenced by the idea of creating a community comanagement system, to create a network of protected areas.

A recent trip to Belize in mid 2014 to make a video on the CBS and its legacy as a community model unexpectedly indicated how fickle governments can be on conservation issues and how strong conservationist communities can be. With the discovery of oil prior to our visit, the government and the Minister of Forests, Fisheries, and Sustainability began to put pressure on the Indigenous NGO SATIIM that was comanaging the Sarstoon-Temash National Park to allow drilling for oil within the park, which was essentially illegal. This initiated an uneasy relationship between NGOs and communities toward the government. A new unpalatable contract was promoted by the government and the NGOs, CBOs, and APAMO attempted to negotiate a better contract. The government then stipulated that all comanagers would be restricted from receiving any funding if they did not sign the contract that would give the government power over the protected areas. Most of the NGOs signed the contract or they would not be able to continue their work, but many communities have resisted. Two indigenous comanagers SATIIM and Itzamna Society have been removed by the government as comanagers. SATIIM and some of the Mayan communities have resisted and won some legal battles against the government with the courts stating that these Mayan communities have a right to these lands as their homelands.

The situation is currently in flux. However, the comanagement system which started with the Belize Audubon Society in the early 1980s, had been working well for over 30 years. In many cases, it was the communities that stimulated the government to create protected areas and had worked hard with little training and resources to protect their lands for Belize, with little support from the government. These same communities are now being disregarded by the Minister of Environment. Belize, which had been an early pioneer of successful comanagement for its protected areas is now dismantling it.

\subsection{Wisconsin - Rugged individualism blocks community power}

While rural southern Wisconsin proved to be fertile ground to stimulate activism and the formation of CBOs, it has proved difficult to catalyze conservation contagion and a sense of regional communalism that has occurred in other countries. This reticence seems to be due to individualism which is a strong element in the American psyche [83].

Community conservation work began in Wisconsin in 1988 with the Ferry Bluff Eagle Council (FBEC) using the CBS as a model [84] (Table 6). However, shortly after successfully working with landowners FBEC discontinued work on the community eagle sanctuary and focused on Eagle Days, an ecotourism project that leaves over \$1 million annually in the Sauk-Prairie community from winter eagle viewing [85; Moermond pers. com.] 


\begin{tabular}{llll}
\hline Group & Date Created & Protected Area & Ha \\
\hline Ferry Bluff Eagle Council & 1987 & Private/public lands & NA \\
\hline Kickapoo Reserve Board & 1996 & Kickapoo Valley Reserve & 3895 \\
\hline Valley Stewardship Network & 1999 & Private/Public Stewardship & NA \\
\hline Blue Mounds Area Project & 1997 & Private Lands & 6364 \\
\hline Sauk Prairie Conservation Alliance & 1998 & Badger Lands & 3425 \\
\hline Kickapoo Community Sanctuary & never & Never accepted & NA \\
\hline
\end{tabular}

Table 6. Wisconsin USA community groups formed.

In 1992, CC created a proposal [86] for a plan to create the Kickapoo Valley Reserve as part of the Kickapoo Community Sanctuary based on the CBS in Belize. The proposal was the resolution to a failed project to create a dam and lake from properties of 144 families by eminent domain that had caused community strife for over 30 years. Much of the proposal was adopted by a committee headed by the Governor's appointee. Through the political process, a 9, 000 hectare reserve was created with a local management board of governor appointees: three members from the adjacent communities, three from the Kickapoo Valley, and three from the state to cover education, environment, and tourism. A few years later, the Ho-Chunk tribe, were given two additional positions on the Board. Although the reserve staff and Board have been successful reserve managers, the community sanctuary idea was omitted from the proposal. Currently in February 2015, another Governor is seeking to dismantle the community-based Kickapoo Valley Reserve Board and place the reserve under the Department of Natural Resources, which has also been considerably downsized. This again shows how changeable government can be.

The initiation of what was to become the Valley Stewardship Network (VSN) originated with the idea of the remainder of the Kickapoo Valley as a buffer zone of the Kickapoo Valley Reserve [84] that harkened back to the creation of the Kickapoo Community Sanctuary, modeled after the Community Baboon Sanctuary in Belize. It led to the creation of a consortium of water quality monitors for the Kickapoo River. VSN has developed a number of programs: to help Kickapoo Valley communities develop management plans, clean up rivers and connect local consumers with local farmers, as well as a strong water monitoring program. VSN's data are used by the Wisconsin Department of Natural Resources and local counties; they have also aided additional conservation organizations that were initiated to fight against factory farms, water bottling initiatives, and frac sand mining.

The Blue Mounds area Project targeted private landowners to protect the biodiversity on their lands with a focus on prairies and oak savannas [84]. It reached $\sim 200$ members and 5260 hectares of land through an ecological extension agent and an active education program.

CC used the Kickapoo Valley Reserve as a model to convert the Badger Army Ammunitions Plant (BAAP) lands into a community reserve. CC first approached Citizens for Safe Water Around Badger (CSWAB), an NGO monitoring the BAAP lands [84], but they never fully 
embraced the Kickapoo model. Eventually, General Services Administration (GSA), whose responsibility was to redistribute the government lands, developed a program for all stakeholders to participate in the process. Community Conservation Coalition for Sauk Prairie (CCCSP) developed to take over project leadership from CSWAB. CCCSP coordinated an education program and produced a proposal to create a natural prairie protected area instead of a chemical-plant-based commercial area. Under a different name, Sauk Prairie Conservation Alliance (SPCA) continued monitoring the land exchange and building demolition process, eventually establishing an office in one of the remaining buildings. The Badger History Group developed as an offshoot of SPCA and helped to gain more community support for maintaining the area as a protected area with a potential recreational role.

The Badger Reuse Committee, established by GSA, worked with the proposed landowners to follow a reuse plan based on the proposal of CCCSP. The lands have been distributed jointly to the Wisconsin Department of Natural Resources, the Ho-Chunk tribe, and the Department of Agriculture who had an experimental farm on the lands. These three landowners signed an agreement with Sauk County, the Department of the Army, and the townships of Merrimac and Sumpter, in which the lands reside, to form the Badger Army Ammunition Plan Oversight and Management Commission. The commission is composed of the Ho-Chunk, Wisconsin DNR, Sauk County and the two townships. There are also stakeholder representatives from CSWAB, SPCA, the Badger History Group, University of Wisconsin-Baraboo, Bluffview Sanitary District, City of Baraboo, Sauk Prairie School District, Village of Sauk City, and the Wisconsin Wildlife Federation with liaisons from The US Army and USDA [87].

The original proposal [86] to create the Kickapoo Community Sanctuary began with the Kickapoo Valley Reserve. However, when the proposal was taken over by a drafting committee of the Kickapoo Valley Advisory Committee coordinated by an appointee of the Governor, much of the community concepts were removed in the revised proposal. When the land was given over to the state the community concept became even more reduced.

Later when we began developing a watershed program with a new proposal [88] to develop a valley wide water quality program, it resulted in Valley Stewardship Network but never developed any concrete interest in unifying the valley into a community sanctuary. In 2007-8, Community Conservation led a workshop to develop community conservation skills in the Kickapoo Valley with the repeated goal of establishing the Kickapoo Community Sanctuary [89]. There was difficulty in getting existing conservation organizations interested in the idea and a yearlong campaign using the Kickapoo Chautaqua, a musical event, to propagate the idea failed. A final push in 2010 resulted instead in developing an annual Earth Day program.

It is puzzling why U.S. villagers, with more formal education, were unable to understand what, presumably, less-educated rural people in India, Ghana, Peru, Belize, and Papua New Guinea, almost immediately grasped. However, this difference became clear considering the individualism that dominates the U.S. psyche [83]. Leopold's Odyssey [83] indicated how, during the late 1930s and 1940s, Leopold struggled with the same problem with U.S. people, that occurs as strong as ever today. In his later life, Leopold saw U.S. conservation losing ground and understood that there were three intertwined elements in U.S. culture that conflicted with conservation and ecological interdependence. He felt that Americans understood themselves 
as isolated individuals acting in their own self-interest for short-term profit. He stated that the "current doctrine of private-profit and public-subsidy" do not require community obligation from private landowners. Leopold stated "We rationalize these defects as individualism, " "but they imply no real respect for the landowner as an individual." He rather called them "bogus individualism" [83 p. 259], which he believed was based on selfishness and shortsightedness. Leopold believed that industrialization, economic determinism, and individualism were destroying the land. It seems the USA has not progressed much today in this respect.

\section{Discussion}

\subsection{Encouraging community conservation organizations and institutions}

Although there is controversy generated around the issue of community conservation on one hand, and a ubiquitous use of the many words connoting community conservation in the literature, there are few definitions of what is meant by the terms [3]. To those that have been successfully working with communities to protect their environment, the controversy is a mute point and only an academic discussion. When carried out with trust between NGOs and communities and when communities are asked for help and given the incentives and responsibilities to protect their environment, they have responded positively. At the center of the success is treating community partners with trust [90], the use of small but adequate budgets used to develop programs, and creating or encouraging the development of simple community organizations as building blocks to develop more complex federations or networks to create an effective solution to stop the spiraling rates of deforestation and loss of biodiversity. Until the conservation community understands and utilizes the numerous rural residents and helps them develop as powerful allies, the world's natural areas will continue to be degraded, fragmented, dwindle and eventually disappear or become ineffective as natural ecosystems.

The basis of successful CCPs is helping communities to create and maintain viable, functional, and empowered community organizations and institutions. By doing this, we are recreating and strengthening new forms of cooperative institutions to replace those that were lost due to colonialism. Community conservation does not replace "traditional" protected areas but strengthens them by creating trusting working relationships between governments, NGOs, and communities and giving communities the power, training, and responsibilities to create a more fulfilled life in relative harmony with the natural world they live in.

In general, community organizations have been based on villages or hamlets as in Belize, Assam, India, Peru, and Madagascar. In Papua New Guinea, clans are the basic unit since villages were a somewhat artificial creation by the Christian missions [55]. Although village units are often heterogeneous in culture and religion, this does not preclude failure [91] and methods can be found to incorporate these variations. Indeed, research on forest management groups shows examples of successful heterogeneous groups [92]. In practice, in the Assam Haathi electric fence project, Bodo and a Rajbanshi, co-developer project leaders work together to inform their respective communities in coordinating the project. In other Assam areas, despite a history of ethnic violence, trusting relationships and positive social incentives help 
diverse communities work together and capitalize on alliances between community members. In the Ultapani-Labanapur villages in the Manas Biosphere, Bodos and Nepalis work together and know each others' languages. In the Kakoijana area, many tribes with Hindus and Christians work together. St Margaret's village, Belize, is composed of refugees from Central America, ex-patriots from the USA and Belizean Creoles that work together. In Peru, the communities involved in these conservation projects are a mix of immigrants from the coast and Andean highlands, with some indigenous.

Although protection of large landscapes is a reason for creating traditional protected areas [23], large landscapes can be protected by community federations [25]. Indeed, there are questions about the effectiveness of traditional protected areas [23]. As in Assam, communities can play a powerful role to support existing protected areas if they are enlisted as full partner conservationists. Communities can also play a major role with nonpublic lands which is important since $90 \%$ of forests are outside of protected areas. Indeed, many of the forests in Nepal are being well protected by communities that have been incorporated into a large, complex network of 15, 000 community forest user groups with international linkages [93].

\subsection{Conservation contagion}

Conservation contagion is a powerful tool that can be encouraged [3]. Existing community networks can be encouraged or new ones created to spread awareness [32]. Workshops and meetings that include people from different areas and cultures can help contagion to jump geographic and cultural gaps. People with extensive contacts are natural net-workers who can propagate contagion across geographical and cultural gaps [32]. Encouraging face-to-face meetings and interactions encourages project dispersal and contagion. Encouraging villagers from one community that has experienced a successful project to inform or help train other communities can be a powerful tool to encourage conservation contagion. We are using villagers in a successful community project in Côte d'Ivoire to influence their neighbors across the Tanoé River in Ghana with the possibility of a transboundary community reserve.

\subsection{Laws and government support of community conservation}

The strongest conservation option is when government, NGOs, and communities work together. Country laws that support community management are also important. In Assam, there was a change in government when the Bodoland Territorial Council (BTC) took over area administration under the Assam state government. The close working relationship with the Minister of Environment, Kampa Borgoyari, strengthened the situation but funding and other actions were not always continuous since there was no formal law in place directing all actors. Thus, we are working with the BTC to see if we can get the law changed to incorporate the successful community action that has protected Assam's forests in recent times.

In contrast to India, Belize created a mechanism for communities to sign MOUs to comanage National Parks and other protected areas. However, the government agencies have lacked the resources and motivation to help train and encourage the community comanagers [75]. Thus, government and NGOs have worked with their own protected areas but neglected the catalytic 
role in strengthening community comanaged protected areas. Now, even worse, the government is working against them.

In Peru, legislation exists to promote the creation of protected areas on titled land (Private Conservation Areas) and on government lands (Conservation Concessions). There also exists a formal protected area category for government/community comanagement with indigenous communities (Communal Reserve). The existence of this legislation has been a main factor in encouraging CCPs in Peru, although the complexities of this legislation and the detailed planning required by government agencies means that these mechanisms are in many cases only viable for CBOs connected to outside NGOs [94]. Similar legislation exists throughout Latin America [95] but, as in Peru, CCP success using these mechanisms depends heavily on communal, local and national government willingness.

Forward-looking governments realize the importance of including communities in the conservation process because they understand that they cannot effectively manage and conserve Protected Areas without the help of local communities [96]. For example, in Belize, our work influenced the government to create new policies for community comanagement institutions [74]. In Assam, India we are striving to convince the new Bodoland tribal government to use existing older laws or to create new laws for community comanagement institutions [2]. In Papua New Guinea, we motivated the government to use the Conservation Area law, a powerful law that had not been used before. In Madagascar, Peru and Ghana which have created existing laws to encourage community-based institutions, we are seeking to use those laws to help communities create CBOs and community-based institutions.

\section{Conclusions: Practitioner knowledge parallels and is supported by research}

As practitioners, many of our independent findings from over 30 years work in 15 countries [3] are supported by social science research [26] and may be considered as important tenets to follow by practitioners of community conservation. Although much of social science on institutions and community organizations has focused on common-pool resource systems, the community-based organizations we have encouraged are not formed for shared resource use but focus on community control and ownership for institutional change to close existing openaccess systems and protect resources. The motivation of the CBOs and NGOs and the complex institutions formed by them, focuses on common good or altruistic incentives rather than competitive or self-serving motivations (what social scientists refer to as "rational egoist" incentives). When economic incentives are reduced, other incentives are more likely to emerge. In some cases, economic incentives are even perceived as a hindrance to conservation by CBOs and they refuse to cooperate with outside conservation agents as a protest against the way big conservation is administered [97].

\subsection{Conservation contagion}

Conservation contagion, observed in Belize, India, and Peru, was noted by a Peruvian villager in a video interview, and similarly Ostrom [26 p.57] noted that "Farm households who 
innovate and are successful or common-property arrangements that increase their joint yield are frequently copied by others. These connections are like a ripple across the landscape rather than strongly linked situations." Conservation contagion shows similar processes to institutional change that happens in small increments or very large changes [26 p.109].

\subsection{Communities create CBOs}

Most analyses of what is necessary for successful resource management by local people include the ability to create microinstitutions to regulate resource use [95]. From conservation practice, catalyzing communities to create microinstitutions is a high priority and communities will readily create $\mathrm{CBO}$ s when given good incentives. Once CBO-NGO trust occurs for conservation methods and solutions, communities are quick to form their own organizations and see the value of creating the large complex institutions. Ostrom [26 p. 221] noted similarly that against conventional theory, many groups have organized on their own [98] or with external help: "local groups of resource users, sometimes by themselves and sometimes with the assistance of external actors, have managed to create viable institutional arrangements for coping with common-pool resource problems." She further notes [26 p. 221] that national governmental agencies have been notably unsuccessful in their efforts to design similar institutions. "Contrary to the conventional theory, many groups in the field have selforganized to develop solutions to common-pool resource problems at a small to medium scale."[98].

\subsection{Polycentric institutions}

Bringing together people from one or more villages can create simple organizations that in turn can be used to build more complex institutions such as federations or networks to comanage regional areas or landscapes as has been accomplished in the Manas Biosphere and the Kakoijana Reserve Forest [25]. While acting in concert when needed, each CBO functions autonomously and can strengthen each other as similarly noted by Ostrom [26 p.280]. McKean [16] notes that such "institutions for managing very large systems need to be layered with considerable devolution of authority to small components to give them flexibility and some control over their fate." It may function better than centralized government institutions because they utilize local knowledge and can be considerably cheaper [26 p. 281-2]. "By utilizing base institutions that are quite small, face-to-face communication can be utilized for solving many of the day-today problems in smaller groups. By nesting each level of organization in a larger level, externalities from one group to others can be addressed in larger organizational settings that have a legitimate role to play in relation to the smaller entities" [99 p.12].

In practice, federations or networks function similarly to what Ostrom has called multi- or polycentric institutions. CC first began encouraging such institutions in the Community Baboon Sanctuary in Belize by catalyzing the seven communities along the Belize River in 1985 to create the CBS Board consisting of members from each village [35, 36]. Later in 1998, CC proposed a more complex community network of all Belizean communities managing protected areas [3] with similar ideas in Madagascar and Ghana, as occurring in Assam and Peru. Ostrom [100] notes that local people may more effectively manage small-scale resources than national agencies because they can better respond to local situations in a field of diversity. 


\subsection{Focus on altruistic rather than selfish incentives}

Whereas much social science research focuses on common pool resources with an assumption of a "rational egoist" mentality for material benefits, CC in practice, emphasizes social, conservation and altruistic incentives to stop an open-access situation. However, in addition to what we have found in practice, there is evidence that community members use altruistic and conservation incentives not just selfish incentives [26 p.102, 110; 101].

The CBOs and NGOs that CC works with seek to protect the common resources from other users who would deplete them. CC encourages simple organizations and complex institutions with the common goal of closing an open-access situation. Thus, all individuals in the group have a similar view. Once protection of the common resource is accomplished then other aspects of common resources pool may occur as the group begins management and seeks sustainable use of some of the resources.

As practitioners, conservation success depends on motivating these aspects rather than economic or self-interest incentives. This may seem counterintuitive, since emphasis in community conservation and ICDP literature has stressed that local communities mainly respond to finances. In practice, that mentality may occur with initial community contact. Researchers are puzzled why communities actively patrol and protect areas even without pay as in Kakoijana, India, Côte d'Ivoire, Peru, and Costa Rica; they do it for the same reason, conservation and the common good. When the communities develop their own institutions and organizations, the rules they place on the community are respected more. Low project finances reduce self-interest incentives and encourages altruistic, cooperative incentives just as external laws and high investment projects do the opposite.

\subsection{Trust}

Trust is important in response to these cooperative and altruistic values [90]. Positive incentives and motivations increase when people are empowered and their self- determination and self-esteem are enhanced. [26 p. 112].

\subsection{Strengthening community partners}

Uphoff et al. [102] note three objectives that lead to success in rural development: productivity, well-being, and empowerment. Well-being includes a wide range of attributes that develops a feeling of self-worth. This is the main reason we involve community members and CBOs in livelihood and economic development, to strengthen our rural partners. Well-being in our partners leads to empowerment. Involving them in meaningful work of conserving and protecting their areas develops pride and fulfillment in what they are doing. Helping them to increase their economic status adds to their sense of well-being.

\subsection{External sanctions}

External sanctions are resisted by communities and are not the best way to proceed and can lead to resentment [26 p. 78-9]. 


\subsection{Group monitoring}

Group monitoring is important [103]. Our rural partners in India, Belize, USA, Ghana, and Peru monitor species, wildlife, illegal activities and other natural resources.

\subsection{Funding}

Large funding with no local input can be harmful since it promotes a "handout" mentality encouraging local groups to capture the funds rather than pursuing their own goals [26 p. 278] and encourages corruption [103]. As noted elsewhere [3], research has shown that people do not always act rationally and in their own interests. Ariely [104] noted that experiments conducted with rural Indian villagers asked to do various tasks for three levels of pay (one day, two weeks, and five months) did not differ in the first two levels but those who could earn the equivalent of five months pay did the task significantly worse. Ariely [104] also noted that using money to motivate people could be counterintuitive. For tasks requiring cognitive ability, low-to-moderate performance-based incentives can help. But if financial incentives are too high, the attention to the reward becomes distracting and creates stress that reduces the level of performance.

\subsection{Support of large institutions}

It is important to have the support of large-scale institutions such as government or international or large regional NGOs, to support the community organizations. Uphoff et al.[102] devote a chapter to the importance of rural community organizations working with government and supporting laws. In Assam, success happened with support of the newly formed Bodo tribal government while in Belize lack of government support has left CBOs in need of help. Similarly, Communal Conservancies in Namibia have flourished because of government and large international organizational support [3].

\section{Author details}

Robert H. Horwich ${ }^{1^{*}}$, Sam Shanee ${ }^{2}$, Noga Shanee ${ }^{2}$, Arnab Bose $^{3}$, Mark Fenn ${ }^{4}$ and Joydeep Chakraborty ${ }^{3}$

*Address all correspondence to: ccc@mwt.net

1 Community Conservation, Gays Mills, Wisconsin, USA

2 Neotropical Primate Conservation, Manchester, UK

3 Natures Foster, Bongaigaon, Assam, India

4 Winrock Foundation, Hanoi, Vietnam 


\section{References}

[1] Persha L, Agrawal A, Chhatre A. Social and ecological synergy: local rulemaking, forest livelihoods, and biodiversity conservation. Science. 2011;331:1606-1608.

[2] Horwich RH, Lyon J, Bose A. What Belize can teach us about grassroots conservation. Solutions. 2011; May-June:51-58.

[3] Horwich RH, Lyon J, Bose A, Jones CB. Preserving biodiversity and ecosystems: catalyzing conservation contagion. In: Moutinho P. (ed.) Deforestation Around the World. Rijeky: InTech; 2012. p. 283-318.

[4] SchmittCB, et al. Global analysis of the protection status of the world's forests. Biol Conser 2009;142:2122-2130.

[5] Brockington D, Duffy R, Igoe J. Nature Unbound. London: Earthscan. 2008. 249 p.

[6] Kiss A. Making biodiversity conservation a land-use priority.In:McShane TO, Wells MP, (eds.) Getting Biodiversity Projects to Work. New York:Columbia University Press; 2004. p. $98-123$.

[7] Kramer R, van Schaik C, Johnson J. (eds.) Last Stand: Protected Areas and the Defense of Tropical Biodiversity. New York: Oxford University Press. 1997.

[8] Oates JF. Myth and Reality in the Rain Forest: How Conservation Strategies Are Failing in West Africa. Berkeley: University of California Press; 1999.

[9] Terborgh J. Requiem for Nature. Washington DC: Island Press; 1999.

[10] Belsky JM. Misrepresenting communities: the politics of community-based rural ecotourism in Gales Point Manatee, Belize. Rural Sociol 1999; 64: 641-666.

[11] Brechin SR, Wilshusen PR, Fortwangler CL, West PC. Reinventing a square wheel: a critique of the new protectionist paradigm in international biodiversity conservation. Soc Natur Res 2002;15:41-64.

[12] McShane TO, and Wells MP. (eds.) Getting Biodiversity Projects to Work. New York: Columbia University Press; 2004. 442 p.

[13] Borrini-Feyerabend G, Pimbert M, Taghi Farvar JC, Kothari A, Renard Y. Sharing Power, Learning by Doing in Co-management of Natural Resources Throughout the World. Cenesta: International Institute for Environment and Development (IIED) and IUCN. 2004. 456 p.

[14] Dowie M. Conservation Refugees. Cambridge: The MIT Press. 2009.341 p.

[15] IUCN. 2003. Policy Matters, 2003;12.

[16] McKean MA. Common property: what is it, what is it good for, and what makes it work? In: Gibson CC, McKean MA, Ostrom E. (eds.) People and Forests Communities, Institutions, and Governance. Cambridge: The MIT Press; 2000. p. 27-55. 
[17] Ostrom E. Governing the Commons: The Evolution of Institutions for Collective Action. New York: Cambridge University Press; 1990. 280 p.

[18] Singleton S. Constructing Cooperation - the Evolution of Institutions of Comanagement. Ann Arbor: The University of Michigan Press; 1998.

[19] Feeny D, Berkes F, McCay BJ, Acheson JM. The tragedy of the commons: twenty-two years later. Human Ecol 1990;18:1-19.

[20] Berkes F. Rethinking community-based conservation. Conserv. Biol. 2004;18: 621-630.

[21] Nagendra H. Do parks work? Impact of protected areas on land cover clearing. Ambio, 2008;37(5): 330-337.

[22] Ostrom E, Nagendra H. Insights on linking forests, trees, and people from the air, on the ground, and in the laboratory. PNAS. 2006;103(51):19224-19231

[23] Hayes TM, Ostrom E. Conserving the world's forests: are protected areas the only way? Indiana Law Rev 2005;38(3):595-617.

[24] Horwich RH, Lyon J. Community conservation: practitioners' answer to critics. Oryx. 2007;41(3): 376-385.

[25] Horwich RH, Islari R, Bose A, Dey B, Moshahary M, Dey NK, Das R, Lyon J. Community protection of the Manas Biosphere Reserve in Assam, India and the endangered golden langur (Trachypithecus geei). Oryx. 2010;44(2):252-260.

[26] Ostrom E. Understanding Institutional Diversity. Princeton: Princeton University Press; 2005. 355 p.

[27] Banana AY, Gombya-Ssembajjwe W. Successful forest management: the importance of security of tenure and rule enforcement in Ugandan forests In: Gibson CC, McKean MA, Ostrom E. (eds.) People and Forests Communities, Institutions, and Governance. Cambridge: The MIT Press; 2000. p. 87-98

[28] Ghate R, Ghate S. Autonomy necessary but not sufficient: comparative study of CFM, Nepal and JFM, India. J Forest Livelihood. 2010;9(1):33-44.

[29] Hayes TA. Parks, people and forest protection: an institutional assessment of the effectiveness of protected areas. World Dev. 2006;34(12):2064-2075.

[30] Molnar A, Scherr S, Khare A. Who conserves the world's forests? Community-driven strategies to protect forests and respect rights. Washington, DC: Forest Trends and Ecoagricultural Partners; 2004.

[31] Varughese G. Population and forest dynamics in the hills of Nepal: institutional remedies by rural communities. In: Gibson CC, McKean MA, Ostrom E. (eds.) People and Forests Communities, Institutions and Governance. Cambridge: The MIT Press. 2000. p. 193-225. 
[32] Christakis NA, Fowler JH. Connected: the Surprising Power of Our Networks and How They Shape Our Lives. New York: Little, Brown and Company; 2009. 333 p.

[33] Gladwell M. The Tipping Point: How Little Things Can Make a Big Difference. New York: Little, Brown \& Company; 2002. 301 p.

[34] Horwich RH, Bernstein SE, Lyon J. Catalyzing community conservation: a guide to developing socially sustainable projects. Unpublished manuscript.

[35] Horwich RH. How to develop a community sanctuary - an experimental approach to the conservation of private lands. Oryx. 1990;24:95-102.

[36] Horwich RH, Lyon J. Experimental technique for the conservation of private lands. J. Med Primatol. 1988;17:169-176.

[37] Srivastava A, Biswas J, Das J, Bujarbarua P. Status and distribution of golden langurs (Trachypithecus geei) in Assam, India. Am J Primatol. 2001;55:15-23.

[38] Horwich RH, Das R, Bose A. Conservation and the current status of the golden langur in Assam, India, with reference to Bhutan. Primate Conserv. 2013;27:77-83.

[39] Ghosh S. Report of wild elephant (Elephas maximus) population estimation in Bodoland Territorial Council (20th-26th Feb 2008), 2008; Report to the Assam Forest Department, Guwahati, Assam

[40] Ministry of Environment and Forests. India tiger estimate 2010. Government of India, National Tiger Conservation Authority, Delhi:Wildlife Institute of India; 2011.

[41] Shanee S, Shanee N. A new conservation NGO, neotropical primate conservation: Project experiences in Peru. Int NGO J. 2009; 4(7): 329-332.

[42] Shanee N. The dynamics of threats and conservation efforts for the tropical Andes hotspot in Amazonas and San Martin, Peru [thesis]. Kent: University of Kent; 2012.

[43] Myers N, Mittermeier RA, et al. Biodiversity hotspots for conservation priorities. Nature. 2000;403(6772): 853-858.

[44] Ross T, Dabek L. 2006. The Tree Kangaroo Conservation Program - communitybased conservation on the Huon Peninsula, Papua New Guinea. Conserv Evid. 2006;3: 47-48. (www.ConservationEvidence.com)

[45] Johnson AH. Monitoring and evaluation of an enterprise-based strategy for wildlife conservation in the Crater Mountain Wildlife Area (Papua New Guinea) [thesis]. Madison: University of Wisconsin; 2000.

[46] Cooter R. Kin goups and the common law process. In: Customary Land Tenure: Registration and Decentralization in Papua New Guinea. Institute of Applied Social and Economic Research. Port Moresby: NRI; 1991;Monograph 29. p. 33-49.

[47] Holzknecht H. Papua New Guinea's land tenure, land use and biodiversity conservation. In: Sekhran N, Miller S. (eds.). Papua New Guinea Country Study on Biological Di- 
versity. Waigani: Papua New Guinea Department of Environment and Conservation; 1994. p. 59-66.

[48] Lamour P. Introduction. In: Customary Land Tenure: Registration and Decentralization in Papua New Guinea. Institute of Applied Social and Economic Research. Port Moresby: NRI. 1991;Monograph 29. p. 1-8.

[49] Eaton, P. Reinforcing traditional tenure: wildlife management areas in Papua New Guinea. In: Stevens S. (ed.) Conservation Through Cultural Survival. Washington DC: Island Press; 1997. p. 225-236.

[50] Collins NM, Sayer JA, Whitmore TC. The Conservation Atlas of Tropical Forests - Asia and the Pacific. New York: IUCN, Simon \& Schuster; 1991. 256 p.

[51] Hedemark M, Sekhran N. Overview of current conservation-oriented policies, legislation and interventions. In: Sekhran, N. Miller S. (eds.) Papua New Guinea Country Study on Biological Diversity. Waigani: Papua New Guinea Department of Environment and Conservation; 1994. p. 339-359.

[52] Horwich RH. A Landowner's Handbook to Relevant Environmental Law in Papua New Guinea. Gays Mills: Community Conservation; 2005. 51 p.

[53] Power, T. Policy making in East Sepik Province. In: Customary Land Tenure: Registration and Decentralization in Papua New Guinea. Institute of Applied Social and Economic Research. Port Moresby: NRI. 1991; Monograph 29. p. 87-100.

[54] Warakai V. The attachment of spiritual and cultural and cultural values to natural resources in Papua New Guinea. In: Sekhran N, Miller S. (eds.) Papua New Guinea Country Study on Biological Diversity. Waigani: Papua New Guinea Department of Environment and Conservation. 1994; p. 319-324.

[55] Wassmann, J. Worlds in mind; the experience of an outside world in a community of the Finisterre range of Papua New Guinea. Oceania. 1993;64:117-145.

[56] Fingleton, JS. Conservation, environment protection and customary land tenure. In: Alcorn JB. (ed.) Papua New Guinea Conservation Needs Assessment. Vol. 1. Conservation issue, CNA Workshop and Recommendations. Washington DC: Biodiversity Support Program. 1993;p. 31-56.

[57] Celcor. 2002 Conservation Areas Act (Chapter 262).

[58] Martin S, Dabek L, Doyle C. Tree Kangaroo Conservation Program in Papua New Guinea 2003; Annual Field Report.

[59] Martin S, Dabek L, Glick J. Tree Kangaroo Conservation Program in Papua New Guinea 2004; Annual Field Report.

[60] Dabek L. et al. Tree Kangaroo Conservation Program 2008; Annual Report.

[61] Martin S, Dabek L, Doyle C, Glick J. Tree Kangaroo Conservation Program in Papua New Guinea 2005; Annual Field Report. 
[62] Whimp, K. Governance, law and sovereignty: enforcing environmental objectives in Papua New Guinea. In: Filer, C. (ed.) The Political Economy of Forest Management in Papua New Guinea. Port Moresby: The National Research Institute (NRI). 1997; Monograph 32. p. 353-367.

[63] Berkes F, George P, Preston RJ. Co-management: the evolution in theory and practice of the joint administration of living resources. Alternatives. 1991;18:12-18.

[64] Horwich RH, Lyon J. Rural ecotourism as a conservation tool. In: Singh TV, Singh S. (eds.) Development of Tourism in Critical Environment. New York: Cognizant Communication Corporation; 1999. p. 102-119.

[65] Ancrenaz M, Dabek L, O'Neill S. The costs of exclusion: recognizing a role for local communities in biodiversity conservation. PloS Biol. 2007;5(11):2443-2448.

[66] Dabek L, et al. Tree Kangaroo Conservation Program 2010; Annual Report.

[67] Horwich RH. Creating Regional Conservation Change in Papua New Guinea, Proposal to Conservation International. 2009.

[68] Fenn M. Learning conservation strategies: a case study of the Parc National d'Andohahela, In: Goodman SM, Benstead JP. (eds.) The Natural History of Madagascar. Chicago: The University of Chicago Press; 2003a. p. 1494-1501.

[69] Raik DB, Decker DJ. 2007. A multisector framework for assessing community-based forest management: lessons from Madagascar. Ecol Soc. 2007;12(10):14 (online) http:// www.ecologyandsociety.org/vol12/art14/

[70] Fenn MD. The spiny forest ecoregion. In: Goodman SM, Benstead JP. (eds.) The Natural History of Madagascar. Chicago: The University of Chicago Press; 2003b. p. 1525-1530.

[71] Erdmann TK. Selected forest management initiatives and issues with an emphasis on the Cadre d'Appui Forestier Project. In: Goodman SM, Benstead JP. (eds.) The Natural History of Madagascar. Chicago: The University of Chicago Press; 2003. p. 1437-1444.

[72] Bernstein SE. Training to develop community-based co-management capacity in Belize [thesis]. Madison: University of Wisconsin; 2005.

[73] Young C, Horwich R. History of protected area designation, co-management and community participation in Belize. In: Balboni BS, Palacio JO. (eds.) Taking Stock: Belize at 25 Years of Independence. Viejo del Carmen: Cubola Books; 2007. p. 123-150.

[74] Meerman JC. Belize Protected Areas Policy and System Plan: Result 2: Protected Area System Assessment \& Analysis PUBLIC DRAFT. 2005. Unpublished report to the protected areas systems plan office.

[75] Catzim A. Project systematization main report. PACT/GEF/UNDP The community co-managed parks system project 1999-2002. PACT: Belmopan; 2002. 
[76] Walker Z, Walker P. The status of protected areas In Belize. PACT:Belmopan; 2009.

[77] Walker Z, Walker. P. The directory of Belize's protected areas. PACT:Belmopan; 2011.

[78] PACT. 1998. Creating a co-managed protected areas system in Belize: A plan for joint stewardship between government and community. Unpublished manuscript.

[79] Producciones de la Hamaca and Community Conservation Consultants. Sarstoon-Temash National Park, Transcript of Stakeholder' Workshop. Cay Caulker: Producciones de la Hamaca; Gays Mills:Orang-utan Press; 1998. 39 p.

[80] Caddy E, Ch'oc G, Paul S. The Sarstoon-Temash Institute of Indigenous Management: a grassroots initiative for social equity and sustainable development. In: MS presented at the IUCN World Congress, Amman, Jordan Oct 10, 2000.

[81] Ravndal V. Final project evaluation, community co-managed park system of Belize. 2002.

[82] Miller M. Belize - Community co-management. Unpublished manuscript presented to US Peace Corps - Belize. 2004.

[83] Lutz-Newton J. Aldo Leopold's Odyssey. Washington DC: Island Press; 2006. 483p.

[84] Horwich RH. Communities saving Wisconsin birds: north and south. Passenger Pigeon. 2005;67:85-98.

[85] Van Koningsveld R, Normand WC, Marcouiller DW. Eagle watchers along the Wisconsin River. Survey Results From the Winter of 1993-1994. 1994.

[86] Horwich RH. Proposal for the Kickapoo Community Sanctuary and Museum of Sustainability. Unpublished manuscript. 1992.

[87] http://www.co.sauk.wi.us/planningandzoningpage/badger-oversite-managementcommission (accessed 2/3/2012)

[88] Horwich RH, Lyon J, Widner, R. A preliminary proposal for the development of a Kickapoo watershed community stewardship program. Unpublished manuscript. 1994.

[89] Horwich RH, et al. Kickapoo Community Sanctuary: keeping our rural past while stepping into the future. Unpublished Manuscript. 2008.

[90] Poteete AR, Janssen MA, Ostrom E. Working Together. Princeton: Princeton University Press; 2010. 346 p.

[91] Baland JM, Platteau JP. Halting Degradation of Natural Resources: Is There a Role For Communities? Food and Agricultural Organization Oxford: Clarendon Press; 1996.

[92] Poteete AR, Ostrom E. Heterogeneity, group size and collective action: the role of institutions in forest management. Dev Change. 2004;35(3):435-462. 
[93] Ojha HR. The evolution of institutions for multi-level governance of forest commons: the case of community forest user groups federation in Nepal. In: Sustaining Commons: Sustaining Our Future; 13 ${ }^{\text {th }}$ IASC International Conference. January 2011.

[94] Shanee N, Shanee S, Horwich RH. Effectiveness of locally run conservation initiatives in north-east Peru. Oryx. 2014;49(2):239-247.

[95] Gibson CC, Becker CD. A lack of institutional demand: why a strong local community in western Ecuador fails to protect its forest. In: Gibson CC, McKean MA, Ostrom E. (eds.) People and Forest Communities, Institutions, and Governance. Cambridge: The MIT Press; 2000. p. 135-161.

[96] Norris S. Madagascar defiant. Bioscience. 2006;56:960-965.

[97] Shanee N. Campesino justification for self initiated conservation actions a challenge to mainstream conservation. J Political Ecol. 2013;20:413-428.

[98] Ostrom, E. A multi-scale approach to coping with climate change and other collective action problems. Solutions. 2010;1(2):27-36. http://www.thesolutionsjournal.com/ node $/ 565$

[99] Ostrom, E. Reformulating the commons. Ambiente $\mathcal{E}$ Sociedade. 2002;10:5-25.

[100] Ostrom, E. Scales, polycentricity, and incentives: designing complexity to govern complexity. In: Guruswamy LD, McNeely JA. (eds.) Protection of Global Biodiversity, Converging Strategies. Durham: Duke University Press; 1998. p. 149-167.

[101] Allendorf T. Residents' attitudes toward three protected areas in southwestern Nepal. Biodiversity Conserv. 2007;16:2087-2102.

[102] Uphoff N, Esman MJ, Krishna A. Reasons For Success, Learning From Instructive Experiences in Rural Development. West Hartford: Kumatrian Press; 1998. 233 p.

[103] Gibson, CC, Williams JT, Ostrom E. Local enforcement and better forests. World Dev. 2005;33(2):273-284.

[104] Ariely, D. The Upside of Irrationality. New York: HarperCollins Publishers; 2010. 334 p. 